\title{
Optimization of cultural conditions for submerged state fermentation of di- gested biogas slurry for production of lignocellulolytic enzymes using Phanaerochaete chrysosporium MTCC 787
}

\author{
Ajit Kaur $^{1^{*}}$ and Urmila Gupta Phutela ${ }^{2}$ \\ ${ }^{1}$ Department of Microbiology, ${ }^{2}$ School of Energy Studies for Agriculture, Punjab Agricultural University, \\ Ludhiana-141004 (Punjab), INDIA \\ "Corresponding author: E-mail: jtkaur89@gmail.com
}

Received: September 10, 2016; Revised received: February 7, 2017; Accepted: August 16, 2017

\begin{abstract}
Growing environmental concerns and increasing demands from end-use sectors have increased the global market for microbial products. Optimizations of production parameters hold great importance for the industry. The present study was aimed at optimization of submerged state fermentation conditions for production of lignocellulolytic enzymes from digested biogas slurry by Phanaerochaete chrysosporium MTCC 787. Enzyme activities for different enzymes i.e. endoglucanase, exoglucanase, $\beta$-glucosidase; xylanase and mannanase; laccase, lignin peroxidase and manganese peroxidise, using $P$. chrysosporium MTCC 787 were maximum at $50 \%$ concentration of digested slurry and showed maximum value of xylanase i.e. $187.41 \mathrm{U} / \mathrm{ml}$. Effect of temperature $\left(25^{\circ} \mathrm{C}, 30^{\circ} \mathrm{C}\right.$ and $\left.35^{\circ} \mathrm{C}\right)$ on lignocellulosic bioconversion showed that at $30^{\circ} \mathrm{C}$, maximum value of manganese peroxidise $(167.5 \mathrm{U} / \mathrm{ml})$ was obtained. Highest enzyme activites were obtained at selected inoculum size i.e. $10^{7}$ spores $/ \mathrm{ml}$, e.g. $85.29 \mathrm{U} / \mathrm{ml}$ xylanase was obtained. Incubation period of 8 days and pH of 7.0 came out to be best conditions for $P$. chrysosporium MTCC787 to produce maximum enzyme activity e.g. xylanase $95.47 \mathrm{U} / \mathrm{ml}$ at $\mathrm{pH} 7.0$ and xylanase $144.96 \mathrm{U} / \mathrm{ml}$ at 8 day incubation.This work presents a novel concept in optimization of fermentation process to produce lignocellulolytic enzymes as this work is focussed on utilization of digested biogas slurry as a substrate for enzyme production and enhancement of the production with microbial source, which is environment friendly.
\end{abstract}

Keywords: Cultural conditions, Digested biogas slurry, Enzymes, Fungi, Lignocelluloses, Optimization

\section{INTRODUCTION}

In the modern era, the technologies related to microbial production of biomolecules like enzymes, antibiotics, metabolites and polymers etc. have matured to a greater extent. Microbes are being used for commercial production of a wide variety of products such as fertilizers in agrochemical sector, biopharmaceuticals and therapeutics in the healthcare sector, biopolymers and biofuels in the energy and environment sectors.

Fermentation is a very versatile process technology for producing such value added products and since fermentation parameters have a high impact upon the viability and economics of the bioprocess, their optimization holds great importance for process development. Especially, the microbial enzyme production is greatly influenced by fermentation conditions such as $\mathrm{pH}$, temperature, substrate concentration and agitation as well as by the incubation period. Moreover, besides the fermentation conditions, the chemical structure, monomer composition, and physicochemical and rheological properties of the final product also change with the type of strain. This in turn allows the industrial production of enzymes with desired specifications via controlling the fermentation conditions, choosing fea- sible feedstocks, and using high-level producer strains (McWilliams, 2011).

Fermentation feedstock can represent almost $30 \%$ of the cost for a microbial fermentation. Thus, to maximize the cost effectiveness of the process, recent work has shifted to use cheaper alternatives such as olive mill wastewater (OMW), syrups, and molasses as the substrate (Robinson and Nigam, 2001). Lignocellulosic biomass is a cheap and abundant alternative for microbial biopolymer production (Ding and Himmel, 2006; Lee, 2005). Thus, the presented work is focussed on using digested biogas slurry, which is a cheaper and easily available feedstock for fermentation.

Fungi possess an efficient hydrolytic system capable to convert lignocellulosic material to essential metabolites for growth (Khalid et al., 2006). Usually, these fungi secrete enzymes, including cellulases (cellobiohydrolases, endoglucanases), hemicellulases (xylanases) and $\beta$-glycosidases. Mutant strains of Trichoderma reesei have been selected that produce extracellular cellulases up to $35 \mathrm{~g} / 1$ (Jorgensen et al., 2003).

Cellulases hydrolyze cellulose to smaller sugar components like glucose and are used in the production of 
fermentable sugars, ethanol, organic acids, detergents, pulp and paper industry, textile industry and animal feed (Chellapandi and Himanshu, 2008; Karmakar and Ray, 2010; Omosajola and Jilani, 2008b). Cellulases can be divided into three major enzyme activity classes; endoglucanses or endo1,4 $\beta$-glucanase (EC 3.2.1.4), cellobiohydrolase (EC 3.2.1.91) and $\beta$ glucosidase (D-glucoside glucohydrolase) (EC 3.2.1.21) (Han et al., 2009). The cellulase systems of the mesophilic fungi Trichoderma reesei and Phanerochaete chrysosporium are the most thoroughly studied (Kaur et al., 2007).

Hemicellulose are heterogeneous polymers built up by pentoses (D-xylose, D-arabinose), hexoses (Dmannose, D-glucose, D-galactose) and sugar acids. There are various enzymes responsible for the degradation of hemicelluloses like endo-1,4- $\beta$-xylanase, $\beta$ xylosidase, $\beta$-glucuronidase and acetylxylan esterase, $\beta$ -mannanase and $\beta$-mannosidase etc. Xylanases are being used as additives in feed for poultry and as additives to wheat flour (Rahman et al., 2007).

Lignin degradation is known to be performed by most of the white-rot fungus like Ceriporiopsis subvermispora. Most of the research concerning biodegradation of lignin has been focused on Phanerochaete chrysosporium, Streptomyces viridosporous, Pleurotous eryngii, Trametes trogii and Fusarium proliferatum (Regalado et al., 1997)

Keeping in view, the present study was aimed to optimize cultural and biochemical parameters for lignocellulolytic enzyme production from P.chrysosporium MTCC 787.

\section{MATERIALS AND METHODS}

Procurement of digested biogas slurry, microbial cultures and chemicals: Digested biogas slurry was procured from a working biogas plant in biogas field laboratory of School of Energy Studies for Agriculture (Punjab Agricultural University), Ludhiana.Standard fungal culturePhanerochaete chrysosporium MTCC 787 was procured from Microbial Type Culture Collection (MTCC), Institute of Microbial Technology (IMTECH), Chandigarh. The culture was maintained on potato dextrose agar media slants at $30 \pm 2^{\circ} \mathrm{C}$ and was stored in refrigerator after sub-culturing. Chemicals used for solutions preparation for enzymatic analysis were of analytical grade and were purchased from Hi-Media, SRL, Sigma and S.D fine chemicals Pvt. Ltd.

Enzymatic analysis of digested biogas slurry: Hundred milliliter of digested biogas slurry was taken in triplicate test tubes each. Hundred $\mathrm{ml}$ of distilled water was added in each test tube containing slurry and was properly mixed. The samples were centrifuged at $10,000 \mathrm{rpm}$ for 15 minutes at $4^{\circ} \mathrm{C}$ to get clear supernatant. The supernatant was used as crude enzyme extract and was analyzed for activities of endoglucanase and exoglucanase by Mandels et al (1976) method. Dinitro-salicylic acid (DNS) method was used for the analysis. The $\beta$-glucosidase activity was measured by the methods of Toyama and Ogawa (1977) and protein content by Lowry et al (1951) method. Lignolytic enzyme laccase was determined by the method of Turner (1974) with some modifications described by Singh et al (1988). Lignin peroxidase activity was determined by the method given by Tien and Kirk (1988). Manganese peroxidase activity was determined by method of Paszczynski et al(1988). Xylanase activity was measured using the method of Singh et al (2000) and Mannanase activity was measured by Growindhagaer et al (1999). Enzyme activities (U/ml of sample) and protein $(\mathrm{mg} / \mathrm{ml}$ of sample) was determined spectrophotometrically using UV-VIS spectrophotometer 2800 model.Reducing sugars produced by cultures were estimated by Miller's (1959) dinitro-salicylic acid (DNS) method.

The enzyme activity was expressed in terms of International units, which is defined as 1 micromole of reducing sugar released per mililitre of enzyme extract, measured as glucose or xylose or mannose. Appropriate dilution factors were used as and when followed during estimation of enzyme activity.

Optimization of process parameters for production of industrial enzymes: Various parameters viz. slurry concentration $(25-75 \%)$, spore concentration $\left(10^{6}-10^{9}\right.$ spores/ml), $\mathrm{pH}$ (4-9), incubation temperature (25-35 C) and varying incubation period (4-16 days) were studied for optimization of ligno-cellulolytic enzymes from P.chrysosporium MTCC 787 using digested biogas slurry as a substrate.For the optimization of slurry concentration, digested biogas slurry mixture (DBS and water) was taken in different concentrations i.e. $25 \%$, $50 \%$ and $75 \%$ and were inoculated with $10^{7}$ spores $/ \mathrm{ml}$ of P.chrysosporium MTCC 787, incubated at $30 \pm 2^{\circ} \mathrm{C}$ for 5 days. The effect of spore concentration was studied by inoculating the diluted digested biogas slurry $(50 \%)$ with inoculum of different sizes of P.chrysosporium MTCC 787 i.e. $10^{6}, 10^{7}$ and $10^{8}$ spores $/ \mathrm{ml}$ spore suspension and incubated at $30 \pm 2^{\circ} \mathrm{C}$ for 8 days in a BOD incubator. For $\mathrm{pH}$, the initial $\mathrm{pH}$ of the substrate (digested biogas slurry) was set to 4.0, 5.0 6.0, 7.0, 8.0 and 9.0 by the addition of buffer solutions of varying $\mathrm{pH}$ and inoculated with mycelia bits (5mm dia) of P.chrysosporium MTCC 787, incubated for 8 days. To study the effect of incubation period, diluted digested biogas slurry $(50 \%)$ inoculated with the 7 day old culture $\left(10^{7}\right.$ spores $\left./ \mathrm{ml}\right)$ was incubated for different incubation period i.e. $4,8,12$ and 16 days at $30 \pm 2^{\circ} \mathrm{C}$ in a BOD incubator. For, incubation temperature, the inoculated flasks of diluted digested biogas slurry of $\mathrm{pH} 7.0$ were incubated at different temperature starting from 20 to $35^{\circ} \mathrm{C}$ with $5^{\circ} \mathrm{C}$ intervals i.e $20,25,30$ and $35^{\circ} \mathrm{C}$ for 8 days in a BOD incubator.

For analysis of enzyme activities, the crude enzyme was 
extracted by centrifugation and enzyme activities were assayed.

\section{RESULTS AND DISCUSSION}

Various cultural conditions like concentration of slurry, incubation temperature, inoculums size, incubation period and $\mathrm{pH}$ etc. affect the production of enzymes. The effect of these parameters on production of lignocellulolytic enzymes was studied using Phanaerochaete chrysosporium MTCC 787 for optimization studies using one variable at a time approach. The results are discussed under following subheads:

Effect of slurry concentration: For optimizing the fermentation processes, the concentration of the substrate plays an important role. It was observed that in digested biogas slurry, enzyme activities for different enzymes i.e. endoglucanase, exoglucanase, $\beta$ glucosidase; xylanase and mannanase; laccase, lignin peroxidase and manganese peroxidase were maximum at $50 \%$ concentration (Table 1). Phanaerochaete chrysosporium MTCC 787 showed higher lignocellulolytic enzyme production i.e. endoglucanase $(1.36 \mathrm{U} / \mathrm{ml})$, exoglucanase $(0.894 \mathrm{U} / \mathrm{ml}), \beta$-glucosidase $(4.377 \mathrm{U} / \mathrm{ml})$; xylanase $(187.41 \mathrm{U} / \mathrm{ml})$ and mannanase $(85.0 \mathrm{U} / \mathrm{ml})$; laccase $(12.0 \mathrm{U} / \mathrm{ml})$, lignin peroxidase $(10.83 \mathrm{U} / \mathrm{ml})$ and manganese peroxidase $(58.34 \mathrm{U} / \mathrm{ml})$.

Fungi prefer a moist environment for their growth as it influence cell growth, the biosynthesis and secretion of enzymes. Lower moisture content causes the reduction in the solubility of the substrate nutrients, low degree of swelling and high water tension (Moo-young et al., 1985; Lon sane et al., 1985). Kundu et al (1983) observed that moisture level for solid state culture below the determined optimal value, leads to enzyme inhibition, whereas above the optimum level, greater enzyme diffusion away from the substrate take place. Laukevics et al (1984) also observed that very little moisture inhibits the growth and enzyme activity of the fungi and also the accessibility to nutrients, while very high moisture compact the substrate, prevent oxygen penetration and facilitates contamination by fast growing bacteria. Fungus growing at lower water ratio offers significant advantage in reducing the risk of contamination, since most bacterial species are unable to grow at reduces moisture level (Kheng and Omar, 2005). However, the optimum moisture level varies with the substrate used, as the various type of substrate have different water holding capacity.

Higher moisture content can cause a reduction in the enzyme yield due to its steric hinderance to cell growth of the enzyme producing strain which results from the reduction in the solid matrix porosity (interparticle spaces). Less porosity interferes with oxygen transfer and in turn influences the cell growth. Maurya et al (2012) reported that the maximum yield of enzyme $(2.29 \mathrm{U} / \mathrm{ml})$ was obtained at $70 \%$ moisture level. However, Mekala et al (2008) reported that at high moisture level $(70 \%)$, the substrate prevents oxygen penetration and facilitates the contamination, whereas the low moisture level inhibits the growth, enzyme activity and accessibility to nutrients. An increase in the initial moisture content of substrate from $55-74 \%$ greatly enhanced the enzyme activity of the broth. However, a further increase to $80 \%$ had a negative effect on the production of the cellulolytic enzymes (Jecu, 2000).

Effect of incubation temperature: Temperature has a profound effect on lignocellulosic bioconversion. Results from Table 2 showed that Phanaerochaete chrysosporium MTCC 787 showed maximum enzyme production at $30^{\circ} \mathrm{C}$. The maximum activities of endoglucanase $(0.997 \mathrm{U} / \mathrm{ml})$, exoglucanase $(0.785 \mathrm{U} / \mathrm{ml}), \beta$-glucosidase $(4.321 \mathrm{U} / \mathrm{ml})$; xylanase $(128.12 \mathrm{U} / \mathrm{ml})$, mannanase $(72.5 \mathrm{U} / \mathrm{ml})$, laccase $(6.67 \mathrm{U} / \mathrm{ml})$, lignin peroxidase $(32.5 \mathrm{U} / \mathrm{ml})$ and manganese peroxidase $(167.5 \mathrm{U} / \mathrm{ml})$ were recordedat $30^{\circ} \mathrm{C}$.

Some of the thermophilic fungi, having maximum growth at or above $45-50{ }^{\circ} \mathrm{C}$ had produced lignocellulases with maximum activity at $50-78{ }^{\circ} \mathrm{C}$ (Wojtczak et al., 1987). The temperature for assaying cellulase activities are generally within $50-65{ }^{\circ} \mathrm{C}$ for a variety of microbial strains e.g. Thielavia terrestris-255, Mycelieopthora fergussi-246C, Aspergillus wentii, Penicillum rubrum, Aspergillus niger, Aspergillus ornatus and Neurospora crassa (Menon et al 1994, Rajendran et al 1994, Steiner et al 1993), whereas growth temperature of these microbial strains was found to be 25-30 ${ }^{\circ} \mathrm{C}$ (Macris et al., 1989).

Effect of spore concentration: For efficient production of lignocellulolytic enzymes, proper inoculum size is required. Results from Table 3 showed that for Phanaerochaete chrysosporium MTCC 787, maximum enzyme activities were found with $10 \square$ spores/ml inoculums.

Results from Table 3 indicate highest endoglucanase activity by Phanaerochaete chrysosporium MTCC $787(0.787 \mathrm{U} / \mathrm{ml})$ at $10 \square$ spores $/ \mathrm{ml}$ spore concentration. Maximum xylanase activity $(85.29 \mathrm{U} / \mathrm{ml})$ was observed in Phanaerochaete chrysosporium MTCC 787 at $10 \square$ spores/ml spore concentration.

Effect of pH: $\mathrm{pH}$ is an important factor affecting enzyme production (Pardo and Forchiassin, 1999). Results from Table 4 showed the effect of varying $\mathrm{pH}$ on the production of industrial enzymes from fungal culture. At pH 7.0 Phanaerochaete chrysosporium MTCC 787 showed maximum exoglucanase (0.658 $\mathrm{U} / \mathrm{ml})$, xylanase $(95.47 \mathrm{U} / \mathrm{ml})$, mannanase $(7.0 \mathrm{U} / \mathrm{ml})$ and lignin peroxidase $3(7.83 \mathrm{U} / \mathrm{ml})$.

The effect of $\mathrm{pH}$ on cellulase production was analysed using Aspergillus niger by Menon et al (1994) and it was reported that $\mathrm{pH} 5.5$ was optimal for maximum cellulase production, while the $\mathrm{pH}$ range of 5.5-6.5 was optimal for $\beta$-glucosidase production from Penicillium rubrum. Eberhart et al (1977) had reported that 
Table 1. Effect of slurry concentration on enzyme production from digested biogas slurry inoculated with mesophilic culture Phanaerochaete chrysosporium MTCC 787.

\begin{tabular}{|c|c|c|c|c|c|c|c|c|}
\hline \multirow{2}{*}{$\begin{array}{l}\text { Slurry } \\
\text { Concen- } \\
\text { tration } \\
(\%)\end{array}$} & \multicolumn{8}{|c|}{ Enzyme activity (U/ml) } \\
\hline & $\begin{array}{l}\text { Endoglu- } \\
\text { canase }\end{array}$ & $\begin{array}{l}\beta- \\
\text { gluco- } \\
\text { sidase }\end{array}$ & $\begin{array}{l}\text { Exoglu- } \\
\text { canase }\end{array}$ & Xylanase & $\begin{array}{l}\text { Man- } \\
\text { nanase }\end{array}$ & Laccase & $\begin{array}{l}\text { Manga- } \\
\text { nese Pe- } \\
\text { roxidase }\end{array}$ & $\begin{array}{l}\text { Lignin } \\
\text { Peroxi- } \\
\text { dase }\end{array}$ \\
\hline 25 & $1.354 \pm$ & $4.356 \pm$ & $0.788 \pm$ & $115.48 \pm$ & $62.0 \pm$ & $9.0 \pm$ & $48.35 \pm$ & $3.67 \pm$ \\
\hline & 0.293 & 0.292 & 0.144 & 0.599 & 0.577 & 0.881 & 0.292 & 0.619 \\
\hline 50 & $1.367 \pm$ & $4.377 \pm$ & $0.894 \pm$ & $187.41 \pm$ & $85.0 \pm$ & $12.0 \pm$ & $58.34 \pm$ & $10.83 \pm$ \\
\hline & 0.293 & 0.290 & 0.145 & 0.593 & 0.576 & 0.881 & 0.588 & 0.640 \\
\hline 75 & $\begin{array}{l}1.094 \pm \\
0.318\end{array}$ & $\begin{array}{l}4.363 \pm \\
0.289\end{array}$ & $\begin{array}{l}0.819 \pm \\
0.146\end{array}$ & $\begin{array}{l}151.28 \pm \\
0.584\end{array}$ & $\begin{array}{l}10.0 \pm \\
0.577\end{array}$ & $\begin{array}{l}3.33 \pm \\
0.485\end{array}$ & $\begin{array}{l}31.7 \pm \\
0.296\end{array}$ & $\begin{array}{l}5.83 \pm \\
0.640\end{array}$ \\
\hline
\end{tabular}

\#Cultural conditions: Incubation period: 5 days; Incubation temperature: $30 \pm 2^{\circ} \mathrm{C}$; Spore concentration: $10^{7}$ spores $/ \mathrm{ml}$ of suspension; $\mathrm{pH}$ : 6;

Table 2. Effect of incubation temperature on enzyme production from digested biogas slurry inoculated with Phanaerochaete chrysosporium MTCC 787.

\begin{tabular}{|c|c|c|c|c|c|c|c|c|}
\hline \multirow{2}{*}{$\begin{array}{l}\text { Spore } \\
\text { concen- } \\
\text { tration } \\
\text { (spores/ } \\
\text { ml) }\end{array}$} & \multicolumn{8}{|c|}{ Enzyme activity (U/ml) } \\
\hline & $\begin{array}{l}\text { Endoglu- } \\
\text { canase }\end{array}$ & $\begin{array}{l}\beta- \\
\text { glucosidase }\end{array}$ & $\begin{array}{l}\text { Exoglu- } \\
\text { canase }\end{array}$ & Xylanase & $\begin{array}{l}\text { Man- } \\
\text { nanase }\end{array}$ & Laccase & $\begin{array}{l}\text { Manga- } \\
\text { nese Pe- } \\
\text { roxidase }\end{array}$ & $\begin{array}{l}\text { Lignin } \\
\text { Peroxi- } \\
\text { dase }\end{array}$ \\
\hline $10^{6}$ & $0.660 \pm 0.061$ & $4.373 \pm 0.291$ & $0.630 \pm 0.058$ & $79.33 \pm 0.587$ & $66.5 \pm 0.600$ & $7.67 \pm 0.619$ & $6.67 \pm 0.619$ & $7.83 \pm 0.115$ \\
\hline $10^{7}$ & $0.787 \pm 0.064$ & $4.496 \pm 0.290$ & $0.756 \pm 0.060$ & $85.29 \pm 0.585$ & $74.5 \pm 0.600$ & $15.64 \pm 0.615$ & $8.34 \pm 0.588$ & $9.34 \pm 0.588$ \\
\hline $10^{8}$ & $0.664 \pm 0.061$ & $4.413 \pm 0.029$ & $0.667 \pm 0.061$ & $74.06 \pm 0.577$ & $65.5 \pm 0.600$ & $14.67 \pm 0.619$ & $5.0 \pm 0.577$ & $6.67 \pm 0.619$ \\
\hline
\end{tabular}

\#Cultural conditions: Incubation period: 5 days; Slurry concentration: $50 \%$; Spore concentration: $10^{7}$ spores $/ \mathrm{ml}$ of suspension; pH: 6

Table 3. Effect of spore concentration on enzyme production from digested biogas slurry inoculated with Phanaerochaete chrysosporium MTCC 787.

\begin{tabular}{|c|c|c|c|c|c|c|c|c|}
\hline \multirow[b]{2}{*}{$\begin{array}{l}\text { Spore } \\
\text { concen- } \\
\text { tration } \\
\text { (spores/ } \\
\text { ml) }\end{array}$} & \multicolumn{8}{|c|}{ Enzyme activity (U/ml) } \\
\hline & $\begin{array}{l}\text { Endoglu- } \\
\text { canase }\end{array}$ & $\begin{array}{l}\boldsymbol{\beta}- \\
\text { gluco- } \\
\text { sidase }\end{array}$ & $\begin{array}{l}\text { Exoglu- } \\
\text { canase }\end{array}$ & Xylanase & $\begin{array}{l}\text { Man- } \\
\text { nanase }\end{array}$ & Laccase & $\begin{array}{l}\text { Manga- } \\
\text { nese Pe- } \\
\text { roxidase }\end{array}$ & $\begin{array}{l}\text { Lignin Pe- } \\
\text { roxidase }\end{array}$ \\
\hline $10^{6}$ & $0.660 \pm 0.061$ & $4.373 \pm 0.291$ & $0.630 \pm 0.058$ & $79.33 \pm 0.587$ & $66.5 \pm 0.600$ & $7.67 \pm 0.619$ & $6.67 \pm 0.619$ & $7.83 \pm 0.115$ \\
\hline $10^{7}$ & $0.787 \pm 0.064$ & $4.496 \pm 0.290$ & $0.756 \pm 0.060$ & $85.29 \pm 0.585$ & $74.5 \pm 0.600$ & $15.64 \pm 0.615$ & $8.34 \pm 0.588$ & $9.34 \pm 0.588$ \\
\hline $10^{8}$ & $0.664 \pm 0.061$ & $4.413 \pm 0.029$ & $0.667 \pm 0.061$ & $74.06 \pm 0.577$ & $65.5 \pm 0.600$ & $14.67 \pm 0.619$ & $5.0 \pm 0.577$ & $6.67 \pm 0.619$ \\
\hline
\end{tabular}

\#Cultural conditions: Incubation period: 5 days; Slurry concentration: $50 \%$; Incubation temperature: $30 \pm 2^{\circ} \mathrm{C} ; \mathrm{pH}: 6$

Table 4. Effect of $\mathrm{pH}$ on enzyme production from digested biogas slurry inoculated with mesophilic culture Phanaerochaete chrysosporium MTCC 787.

\begin{tabular}{lllllllll}
\hline pH & \multirow{2}{*}{$\begin{array}{l}\text { Endoglu- } \\
\text { canase }\end{array}$} & $\boldsymbol{\beta}$-glucosidase & $\begin{array}{l}\text { Exoglu- } \\
\text { canase }\end{array}$ & Xylanase & $\begin{array}{l}\text { Man- } \\
\text { nanase }\end{array}$ & Laccase & $\begin{array}{l}\text { Manganese } \\
\text { Peroxidase }\end{array}$ & $\begin{array}{l}\text { Lignin } \\
\text { Peroxidase }\end{array}$ \\
\hline 5 & $0.605 \pm 0.115$ & $4.376 \pm 0.590$ & $0.306 \pm 0.057$ & $29.48 \pm 0.599$ & $1.5 \pm 0.288$ & $4.5 \pm 0.600$ & $7.06 \pm 0.577$ & $2.5 \pm 0.600$ \\
6 & $0.640 \pm 0.116$ & $4.312 \pm 0.586$ & $0.596 \pm 0.066$ & $38.61 \pm 0.612$ & $2.0 \pm 0.577$ & $2.34 \pm 0.059$ & $8.34 \pm 0.588$ & $3.34 \pm 0.588$ \\
7 & $1.371 \pm 0.062$ & $4.378 \pm 0.590$ & $0.658 \pm 0.060$ & $95.47 \pm 0.598$ & $7.0 \pm 0.577$ & $7.87 \pm 0.646$ & $8.67 \pm 0.619$ & $7.83 \pm 0.115$ \\
8 & $1.043 \pm 0.438$ & $4.368 \pm 0.598$ & $0.603 \pm 0.057$ & $48.12 \pm 0.355$ & $5.0 \pm 0.577$ & $3.67 \pm 0.619$ & $7.34 \pm 0.588$ & $6.34 \pm 0.588$ \\
\hline
\end{tabular}

\#Cultural conditions: Incubation period: 5 days; Slurry concentration: $50 \%$; Incubation temperature: $30 \pm 2^{\circ} \mathrm{C}$; Spore concentration: $10^{7}$

production and release of cellulase depended on the $\mathrm{pH}$ of the medium. His observations indicated that extracellular release of cellulase from Neurospora crass occurred at $\mathrm{pH} 7$, whereas the enzyme remained accumulated in the cell at $\mathrm{pH} 7.5$. Similarly, $\mathrm{pH} 7$ was suit- able for extracellular production of cellulase from the Humicola fuscoatra (Rajendran et al., 1994). Further, the adsorption behaviour of cellulases was also affected by the $\mathrm{pH}$ of the medium (Kim et al., 1988; Mukhopadhyey and Nandi, 1999).Lignolytic enzymes like 
Table 5. Effect of incubation period on enzyme production from digested biogas slurry inoculated with mesophilic cultures.

\begin{tabular}{|c|c|c|c|c|c|c|c|c|}
\hline \multirow{2}{*}{$\begin{array}{l}\text { Incuba- } \\
\text { tion } \\
\text { period }\end{array}$} & \multicolumn{8}{|c|}{ Enzyme activity (U/ml) } \\
\hline & $\begin{array}{l}\text { Endoglu- } \\
\text { canase }\end{array}$ & $\begin{array}{l}\beta- \\
\text { glucosidase }\end{array}$ & $\begin{array}{l}\text { Exoglu- } \\
\text { canase }\end{array}$ & Xylanase & $\begin{array}{l}\text { Man- } \\
\text { nanase }\end{array}$ & Laccase & $\begin{array}{l}\text { Manga- } \\
\text { nese Pe- } \\
\text { roxidase }\end{array}$ & $\begin{array}{l}\text { Lignin } \\
\text { Peroxi- } \\
\text { dase }\end{array}$ \\
\hline 4 & 0.748 & 5.05 & 0.062 & 110 & 55.5 & .399 & $7.97 \pm 0.661$ & $1.78 \pm 0.303$ \\
\hline 8 & $0.784 \pm 0.073$ & $5.290 \pm 0.580$ & $0.785 \pm 0.060$ & $144.96 \pm 0.869$ & $58.5 \pm 0.600$ & $7.43 \pm 0.594$ & $12.65 \pm 0.616$ & $4.89 \pm 0.316$ \\
\hline 12 & $0.779 \pm 0.066$ & $5.225 \pm 0.582$ & $0.635 \pm 0.029$ & $136.89 \pm 0.649$ & $46.5 \pm 0.600$ & $7.41 \pm 0.593$ & $11.56 \pm 0.606$ & $4.87 \pm 0.646$ \\
\hline 16 & $0.766 \pm 0.058$ & $5.144 \pm 0.599$ & $0.483 \pm 0.060$ & $133.73 \pm 0.649$ & $48.0 \pm 0.600$ & $6.67 \pm 0.594$ & $11.08 \pm 0.625$ & $3.68 \pm 0.649$ \\
\hline
\end{tabular}

\#Cultural conditions: Slurry concentration: $50 \%$; Incubation temperature: $30 \pm 2^{\circ} \mathrm{C} ; \mathrm{pH}: 8$; Spore concentration: $10^{7}$

laccase showed $\mathrm{pH}$ optimum at neutral $\mathrm{pH}$, both unusual properties for most known fungal laccases and with guaiacol and syringaldazine the $\mathrm{pH}$ optima were rather broad: 5-7.5 and 6-7, respectively (Dhakar and Pandey 2013). The optimum $\mathrm{pH}$ for laccase production from Trametes hirsuta MTCC 11397 was between 5.5 and 7.5. (Baldrian 2006; Jordaan and Leukes 2003).

Effect of incubation period: Incubation period plays an important role in substrate utilization and enzyme production. Maximum activity of enzymes was obtained at 8 day of incubation in most of the cultures (Table 5).Out of all the enzymes analyzed, xylanase $(144.96 \mathrm{U} / \mathrm{ml})$ showed highest activity in Phanaerochaete chrysosporium MTCC 787 after 8 days of incubation.

\section{Conclusion}

Submerged state fermentation of digested biogas slurry is a novel idea for production of lignocellulolytic enzymes, which provides a clean and green energy technology. This production is enhanced with the use of fungus Phanaerochaete chrysosporium MTCC 787 at $50 \%$ concentration of slurry, $30{ }^{\circ} \mathrm{C}$ incubation temperature, $10 \square$ spores $/ \mathrm{ml}$ of inoculum size, 8 day of incubation period and $7 \mathrm{pH}$ etc. This technology if used commercially can be an energy efficient way of utilizing the digested biogas slurry and will add to its value.

\section{ACKNOWLEDGEMENTS}

The authors acknowledge the financial support provided by University Grants Commission (UGC), New Delhi, for completion of this work.

\section{REFERENCES}

Baldrian, P. (2006). Fungal laccases-occurrence and properties. FEMS Microbiol. Rev. 30: 215-242.

Chellapandi, P. and Himanshu, M. (2008). Production of endoglucanase by the native strains of Streptomyces isolates in submerged fermentation. Braz. J. Microbiol., 39: $122-27$

Dhakar, K., Pandey, A. (2013). Laccase production from a temperature and $\mathrm{pH}$ tolerant fungal strain of Trametes hirsutaMTCC 11397.Enz. Res. 10: 1-9.

Ding, S. and Himmel, M. (2006). The maize primary cell wall microfibril: A new model derived from direct visualization. J. Agric. Food Chem. 54: 597-606.

Eberhart, B.M., Beek, R.S., Goolsby, K.M. (1977). Cellulose of Neurospora crassa. J. Microbiol. 130:181-86

Großwindhager, C., Sachslehner, A., Nidetzky, B. and Haltrich, D. (1999). "Endo- $\beta$-1,4-D-mannanase is efficiently produced by Sclerotium (Athelia) rolfsii under derepressed conditions," J. Biotechnol. 67(2-3): 189-203.

Han, L., Feng, J., Zhu, C., and Zhang, X. (2009). Optimizing cellulase production of Penicillium waksmanii F102 with response surface methodology. African J. Biotechnol. 8: 3879-86.

Jecu, L. (2000). Solid state fermentation of agricultural waste for endogluconase production. Indus. Crops Prod. 11: 1 -5 .

Jordaan, J., Leukes, W.D. (2003). Isolation of a thermostable laccase with DMAB and MBTH oxidative coupling activity from a mesophilic white rot fungi. Enz. Microbial. Technol. 33: 212-219.

Jørgensen, H., Erriksson, T., and Börjesson, J. (2003). Purification and characterisation of five cellulases and one xylanases from Penicillium brasilianum IBT 20888. Enzyme Microb. Technol.32: 851-61.

Karmakar, M., and Ray, R. (2010). Extra Cellular Endoglucanase Production by Rhizopus oryzae in Solid and Liquid State Fermentation of Agro Wastes. Asian J. Biotechnol. 2: 27-36.

Kaur, J., Chadha, B., Kumar, B., and Saini, H. (2007). Purification and characterization of two endoglucanases from Melanocarpus sp. MTCC 3922. Bioresour. Technol. 98: 74-81.

Khalid, M., Yang, W., Kishwar, N., Rajput, Z. and Arijo, A. ((2006). Study of cellulolytic soil fungi and two nova species and new medium. J. Zhejiang Univ. SCIENCE B. 7: 459- 66 .

Kheng, P.P. and Omar, C.I. (2005). Xylanase production by local fungal isolates, Aspergillus niger USM AI 1 via solid state fermentation using palm kernel cake as substrate. J. Sci. Technol. 27(2): 325-36.

Kim, D.W., Yang, J.H., Jeong, Y.K. (1988). Adsorption of cellulose from Trichoderma viride on microcrystalline cellulose. Appl. Microbiol. Biotechnol. 28:148-54

Kundu, A.B., Ghosh, B.S., Ghosh, B.L. and Ghose, S.N. (1983). J. Ferm. Technol. 61: 185 (cited by Rolz (1984) Annual report on fermentation process 7: 213-356.

Laukevics, J.J., Aspite, A.F., Veistures, V.E. and Tengerdy, R.P. (1984). Solid state fermentation of wheat straw to fungal protein. Biotechnol. Bioeng. 26: 1465-74.

Lee, Y. (2005). Oxidation of Sugarcane Bagasse Using a Combination of Hypochlorite and Peroxide. A Thesis Submitted for partial fulfillment for the degree of Master of Science in Food Science.

Lonsane, B.K., Ghildyl, N.P., Budiatman, S. and Ramakrishna, S.V. (1985). Enzyme Microbial. Technol. 7: 258-65. 
Lowry, O.H., Rosebrough, N.J., Farr, A.L. and Randall, R.J. (1951). Protein measurement with folin-phenol reagent. J. Biol. Chem. 193: 265-75.

Macris, B.J., Kekos, D., Evangelidou, E. (1989). A simple and inexpensive method for cellulose and -glucosidase production by Neurospora crassa. Appl. Microbiol. Biotechnol., 31:150-51

Mandels, M. (1976). Microbial sources of cellulases. In: Wilkie CR, editor. Cellulose as a Chemical and Energy Resource. New York: John Wiley and Sons 81-105.

Maurya, D.P., Singh, D., Pratap, D. and Maurya, J.P. (2012). Optimization of solid state fermentation conditions for the production of cellulase by Trichoderma reesei. $J$. Environ. Biol., 33: 5-8.

McWilliams, A. (2011). Microbial products: technologies, applications and global markets. BCC Research. http:// www.giiresearch.com/report/bc180728-glob-microbialprod.html. Accessed 16 Feb 2012

Mekala, N.K., Singhania, R.R., Sukumaran, R.K. and Panday, A. (2008). Cellulase production under solid state fermentation by Trichoderma reesei RUT C30: Statistical optimization of process parameters. Appl. Biochem. Biotechnol., 151: 122-31.

Menon, K., Rao, K.K., Pushalkar, S. (1994). Production of glucosidase by Penicillium rubrum $\mathrm{O}$ stall. Indian $\bar{J}$. Exp. Biol. 32:706- 09

Miller, G.J. (1959). Use of dinitrosalicylic acid reagent for the determination of reducing sugars. Analyt. Chem., 31: 426-28.

Moo-Young, M., Moreira, A.R. and Tengerdy, R.P. (1985). Filamentous Fungi, 4: 117-44.

Mukhopadhyey, S. and Nandi, B. (1999). Optimization of cellulose production by Trichoderma reesei ATTCC 26921 using a simpliWed medium on water hyacinth biomass. J. Sci. Ind. Res., 58:107-11

Omosajola, P., and Jilani, O. (2008b). Cellulase production by Trichoderma longi, Aspergillus niger, Saccharomyces cerevisae cultured on waste materials from orange. Pak. J. Biol. Sci., 11: 2382-88.

Pardo, A.G., Forchiassin, F. (1999). Influence of temperature and $\mathrm{pH}$ on cellulase activity and stability in Nectria catalinensis. Rev. Argent. Microbiol., 31:31-35
Paszczynski, A.J., Ronald, L.C. and Van, B.H. (1988). Manganese peroxidase of Phanerochaete chrysosporium. Methods Enzymol., 161:264-70.

Rahman, S.H., Choudhury, J.P., Ahmad, A.L., Kamaruddin, A.H. (2007). Optimization studies on acid hydrolysis of oil palm empty fruit bunch Wber for production of xylose. Bioresour. Technol., 98:554-59

Rajendran, A., Gunasekaran, P., Lakshmanan, M. (1994). Cellulase activity of Humicola fuscoatra. Indian J. Microbiol., 34:289-95

Regalado, V., Rodriguez, F., Carnicero, A., Fuente, G. and Falcon, M.A. (1997). Lignin degradation and modification by soil inhabiting fungus Fusarium proliferatum. Appl. Environ. Microbiol., 63: 3716-18.

Robinson, T., and Nigam, S. (2001). Solid-state fermentation: A promising microbial technology for secondary metabolite production, Appl. Microbiol. Biotechnol., 55: 284-89.

Singh, R.P., Garcha, H.S. and Khanna, P.K. (1988). Laccase production by Pleurotus spp. Ind. J. Microbiol., 28: 3841.

Singh, S., Pillay, B. and Prior, B.A. (2000). Thermal stability of $\beta$-xylanases produced by different Thermomyces lanuginosus strains. Enzyme. Microbiol. Technol., 26:502-08

Steiner, J., Saccha, C., Enzyaguirre, J. (1993). Culture condition for enhanced cellulose production by a native strain of Penicillium purpurogenum. World J. Microbiol. Biotechnol., 10:280-84

Tien, M. and Kirk, T.K. (1988). Lignin peroxidase of Phanerochaete chrysosporium.Methods Enzymol., 161: 238-49.

Toyama, N. and Ogawa, K. (1977). In: Ghose T K (Ed.), International Course on Biochemical Engineering Bioconversion.

Turner, E.M. (1974). Phenoloxidase activity in relation to substrate and development stage in mushroom Agaricus bisporus. Trans. Mycol. Soc., 63: 541-47.

Wojtczak, G., Breuil, C., Yamuda, J., Saddler, J.N. (1987). A comparision of the thermostability of cellulose from various thermophilic fungi. Appl. Miocrobiol. Biotechnol., 27: 82-87 